\title{
An Experimental Investigation on the Effects of Nanofluid and Peltier Element on Diesel and Biodiesel Blends in Compression Ignition Engine
}

\author{
R. Manimaran ${ }^{1 *}$, K. Murugu Mohan Kumar ${ }^{2}$ \\ ${ }^{1}$ School Of Mechanical Engineering, SASTRA Deemed University, Thanjavur, Tamil Nadu, India. \\ ${ }^{2}$ School Of Mechanical Engineering, SASTRA Deemed University, Thanjavur, Tamil Nadu, India. \\ *Corresponding Author E-Mail:Manimaran@Mech.Sastra.Edu
}

\begin{abstract}
This research work discusses the experimental investigations on the combined effects of Nanofluid and Peltier elements in mahua biodiesel blends with diesel fuel. The fuel test was carried out in a single cylinder ata constant speed (1500 rpm) direct injection diesel engine. Mahua oil used as an effective alternative to diesel fuel and mahua methyl ester derived from transesterification process. The mahua biodiesel was blended with diesel and nanofluid on volume fraction like M10, M20, M10* and M20*. Nanofluidin biodiesel blends with diesel resultsefficient combustion leads to improvement in engine performance, butit causes an increase in viscosity. Peltier element was used to reduce biodiesel blend viscosity with the principle of thermo-electricity.Finally, this research work concludes Mahua biodiesel $20 \%+$ diesel $80 \%+2 \mathrm{ml}$ of aluminium oxide nanofluid (M20*) fuel act as an effective alternative fuel.M20"blend results in better engine combustion, performance (improved BTE and optimum BSEC) and decreased emission of NOx, Smoke and increased $\mathrm{HC}, \mathrm{CO}$ emissions as compared to diesel fuel operation at peak power outputs.
\end{abstract}

Keywords: Mahua methyl ester, Nanofluid, Peltier element, Transesterification process.

\section{Introduction}

IN the present work, Mahua biodiesel is selected based on the oxygen content, flash point, solubility in diesel fuel and stability and fuel properties such as viscosity and cetane number. Though there are many biodiesels close to diesel properties, the reason for choosing mahua is the economic impact it has on the other biodiesel resources through its tree's products and by-products. Aluminium oxide Nanofluidblended with biodiesel blends at volume fractions. These blends are preheating using Peltier element is the new method of absorbing heat from engine exhaust and produce the useful form of energy in a process. Many heat recovery techniques have been employed in IC engines to preheat the fuel. Here performance and emission characteristics of the blends like M10, M20, M10*\& M20* are compared with those of diesel fuel. These blends are tested on single cylinder direct injection diesel engine using mechanical fuel injection system. The performance and emission characteristics of diesel fuel and biodiesel produced from Mahua oil and its blends (B10, B20, B30, and B40) as compared with different engine loads. From the results, they observed that $20 \%$ of mahua biodiesel blend with diesel showed the best engine performance [1]. The effects of additive nanoparticles on the individual fuel properties, the engine performance and emissions were studied, and the dosage of the additive optimised. The emission percentage of hydrocarbon and Oxides of nitrogen are reduced appreciable amount with the addition of cerium oxide nanoparticles [2]. The effect of alumina $\left(\mathrm{Al}_{2} \mathrm{O}_{3}\right)$ nanoparticles (ANP) on the performance and emission characteristics of biodiesel blends of Lard Oil Methyl Ester (LOME) and its blends (B10, B20, and B30) on a compression ignition engine was investigated. All the biodiesel blends concluded that $\mathrm{B} 20+100 \mathrm{ANP}$ had a maximum reduction in $\mathrm{HC}$ concentration, CO percentage, and Smoke opacity [5]. Peltier element (thermoelectric device) as used for absorbing and releasing the adsorption and desorption heat generation. The cold and warm effects of Peltier element exist in this experimental research work. The Peltier element efficiently releases the heat generation of adsorption and desorption due increase in electric current [7]

\section{Materials and Methods}

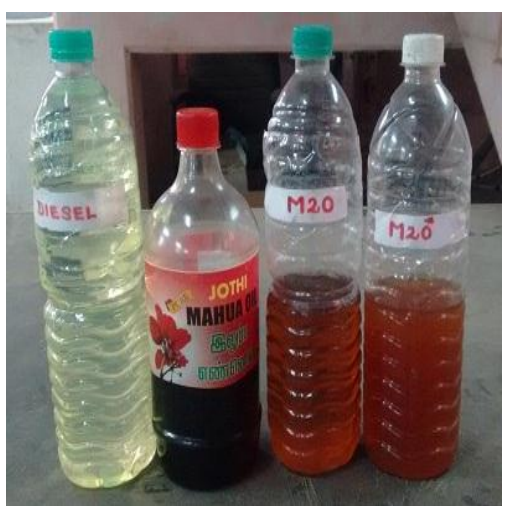

Fig. 1: Diesel and Mahua biodiesel blends

Due to their large population and excellent growth rate, Mahua oil (MadhucaIndica) used as a substitute for diesel in compression ignition engines. It is necessary to improve the fuel properties of 
compression ignition engines and to investigate the working of Mahua oil in diesel engines. Among the several non-edible seed oils, Mahua oil has preferred because of its abundance growth in India and stress-freesubstitutable nature for hydrocarbon fuels. The Diesel and Mahua biodiesel blends are shown in fig. 1 and its properties in table I and II.

Table I: Properties of Diesel and Mahua Biodiesel

\begin{tabular}{|l|l|l|}
\hline Properties & Diesel & Mahua biodiesel \\
\hline Kinematic viscosity at $40^{\circ} \mathrm{C}(\mathrm{cSt})$ & 3.05 & 5.71 \\
\hline Density at $15^{\circ} \mathrm{C}\left(\mathrm{kg} / \mathrm{m}^{3}\right)$ & 832 & 890 \\
\hline Flash point $\left({ }^{\circ} \mathrm{C}\right)$ & 56 & 129 \\
\hline Cetane number & 45 & 51 \\
\hline Calorific value $(\mathrm{kJ} / \mathrm{kg})$ & 43000 & 39150 \\
\hline & \multicolumn{2}{|l|}{} \\
\hline
\end{tabular}

Table II: Properties of Mahua Biodiesel Blends

\begin{tabular}{|l|l|l|l|l|}
\hline Properties & M 10 & M 20 & M 10* & M 20* \\
\hline Kinematic viscosity at $40^{\circ} \mathrm{C}(\mathrm{cSt})$ & 3.63 & 4.24 & 3.8 & 4.3 \\
\hline Density at $15^{\circ} \mathrm{C}\left(\mathrm{kg} / \mathrm{m}^{3}\right)$ & 837 & 843 & 839 & 846 \\
\hline Flash point $\left({ }^{\circ} \mathrm{C}\right)$ & 119 & 123 & 112 & 120 \\
\hline Cetane number & 46 & 48 & 47 & 50 \\
\hline Calorific value $(\mathrm{kJ} / \mathrm{kg})$ & 42460 & 42120 & 42380 & 42089 \\
\hline & & & & \\
\hline
\end{tabular}

Nanoparticles are given a high surface-to-volume ratio to have more reactive surfaces, allowing them to act as more efficient chemical catalysts, thus ensuring the complete combustion of biodiesel blends. The presence of these particles also increases fuel-air mixing in the fuel. The aluminium oxide nanofluidis shown in fig. 2.Peltier is an element working on the basic principle of Thermoelectricity (TE) as shown in fig. 3. This effect interrelates between the electronic and thermal properties of a system. There are two primary thermoelectric effects - the Seeback effect and the Peltier effect.The Peltier element is used to absorb the exhaust gas heat and convert into electrical charge due to the activation of n-type and p-type semiconductors with the temperature difference.

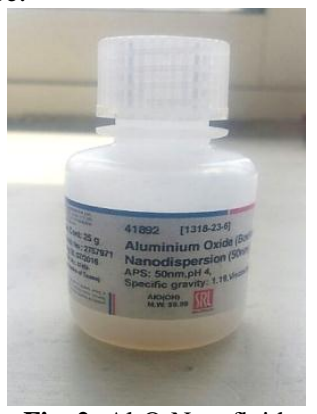

Fig. 2: $\mathrm{Al}_{2} \mathrm{O}_{3}$ Nanofluid

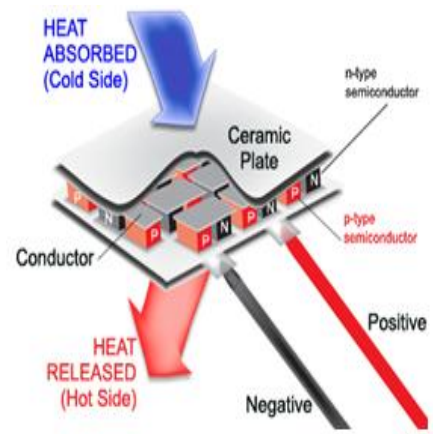

Fig. 3: Peltier element

\section{Experimental Setup}

The Kirloskar engine can withstand higher pressures encountered during tests because of its rugged construction. In this setup was coupled with eddy current dynamometer and these cooled by water source. Initially, one Peltier element placed over the exhaust pipe which extracts the heat at one side and produces electricity (i.e., D.C current) in the form of voltage. This D.C voltage is stored in the battery for later use. The experiment is carried out in 5HP, single cylinder, and direct injection diesel engine at a constant speed of $1500 \mathrm{rpm}$. Peltier element was fixed in the engine exhaust manifold and connected to the rechargeable battery. When the test engine is operating with base diesel fuel, the wastage of exhaust manifold gas heat is reused using Peltier element 1. For preheating purpose, the Peltier element 2 have fixed on biodiesel tank. When the test engine operates on biodiesel blends, their high viscosity could be reduced up to 2 to $3 \mathrm{cSt}$ by using Peltier element. This reduction of fuel viscosity improved the fuel combustion. The experimental setup is shown in fig. 4 , and its specification in Table III.

Table III: Engine Specification

\begin{tabular}{|l|l|}
\hline \multicolumn{2}{|c|}{ Table III: Engine Specification } \\
\hline Engine Manufacturer & Details \\
\hline Type & Vertical oil engines ltd \\
\hline Bore & $87.5 \mathrm{~mm}$ \\
\hline Stroke & $110 \mathrm{~mm}$ \\
\hline Number of cylinders & 1 \\
\hline Compression ratio & $17.5: 1$ \\
\hline Speed & $1500 \mathrm{rpm}$ \\
\hline Maximum Power & $5.2 \mathrm{~kW}$ \\
\hline Cooling system & Water \\
\hline Fuel injection timing & $23^{\circ} \mathrm{bTDC}$ \\
\hline Injector type & Mechanical injector \\
\hline Injection Pressure & $200 \mathrm{bar}$ \\
\hline & \\
\hline
\end{tabular}

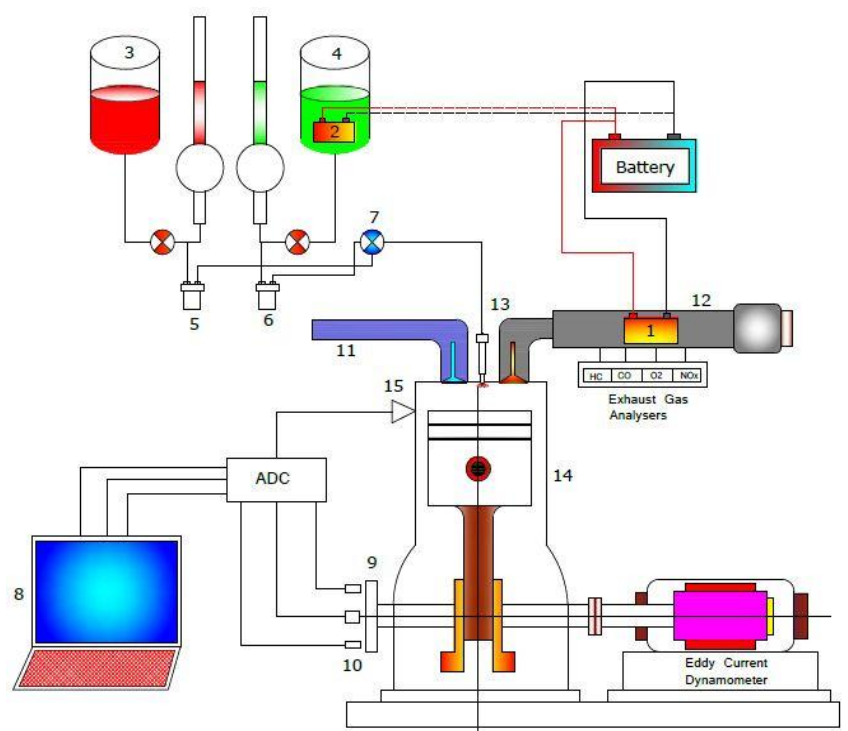

Fig. 4: Engine experimental setup

\begin{tabular}{|c|c|c|}
\hline $\begin{array}{l}1 \text { - Peltier Element } \\
\text { I }\end{array}$ & 6 - Biodiesel Filter & 11 - Intake manifold \\
\hline $\begin{array}{l}2 \text { - Peltier Element } \\
\text { II }\end{array}$ & 7 - Control Valve & 12 - Exhaust manifold \\
\hline $\begin{array}{l}3 \text { - Diesel Fuel } \\
\text { Tank }\end{array}$ & $\begin{array}{l}8 \text { - Data Acquisition } \\
\text { System }\end{array}$ & 13 - Fuel Injector \\
\hline 4 - Biodiesel Tank & $\begin{array}{l}9-\text { TDC Position } \\
\text { Encoder }\end{array}$ & 14 - Diesel Engine \\
\hline $\begin{array}{l}5-\text { Diesel Fuel } \\
\text { Filter }\end{array}$ & $10-$ Speed Sensor & $\begin{array}{l}15 \text { - Pressure } \\
\text { Transducer }\end{array}$ \\
\hline
\end{tabular}

\section{Results and Discussion}

\section{Performance characteristics}

Figure 5 shows the variation of brake thermal efficiency (BTE) with brake power (BP) at maximum engine power output. The BTE values of M10, M20 are $5.15 \%$ and $7.51 \%$ less than diesel. Due to increase in density, viscosity and lower calorific value of the biodiesel blends which resulted in poor fuel atomization and 
mixture preparation leads to inferior combustion. But for the brake thermal efficiency of $\mathrm{M}^{*}{ }^{*}, \mathrm{M} 20^{*}$ is $4.42 \%$ and $6.58 \%$ less than diesel when compared to M10, M20 biodiesel blends. The percentage increase in $\mathrm{M}^{*} 0^{*}$ and $\mathrm{M} 20^{*}$ values are $0.76 \%$ and $0.93 \%$. The addition of Nanofluid with biodiesel to reduce ignition delay and improves more reactive surfaces of fuel molecules with air, which leads to improvement in performance and combustion of biodiesel blends.

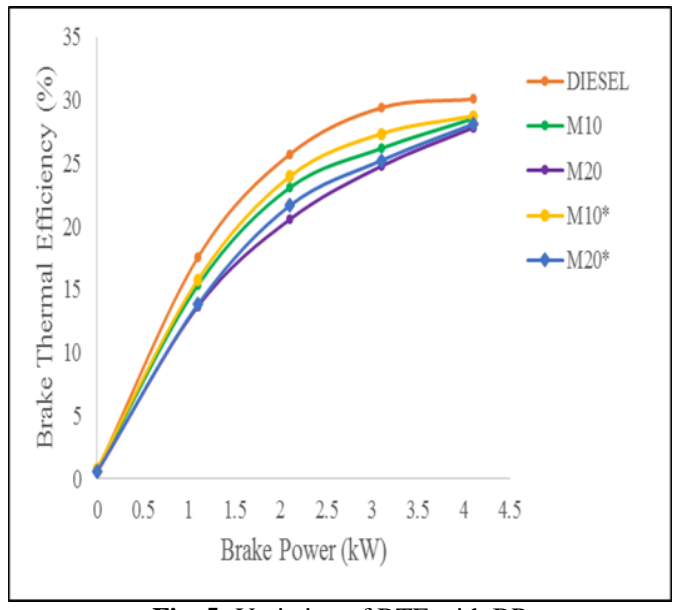

Fig. 5: Variation of BTE with BP

The variation of brake specific energy consumption (BSEC) with brake power at peak power output as shown in fig. 6. The biodiesel blends of M10 and M20 values are $11.19 \%$ and $18.94 \%$ increase than diesel due to higher heating value, and density of biodiesel blends resulted in incomplete combustion. But for M10* and M20* blends with M10, M20 values have resulted in percentage decrease of $2.98 \%$, and $1.56 \%$ and these values are still more than diesel fuel.

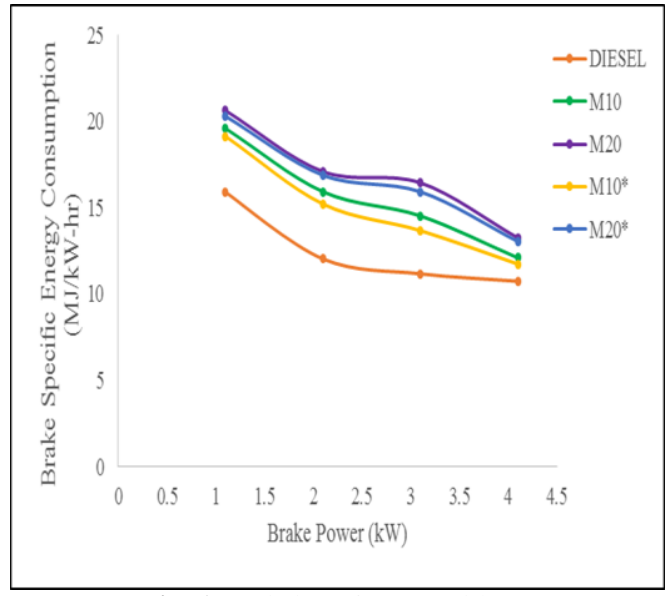

Fig. 6: Variation of BSEC with BP

\section{Combustion parameters}

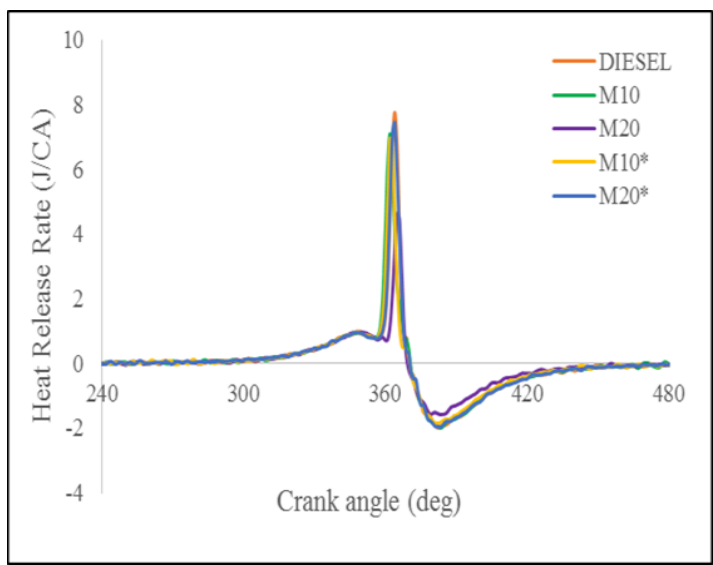

Fig. 7: Variation of HRR with crank angle
Figure 7 shows the variation of net heat release rate of diesel and biodiesel blends. It could observe that the biodiesel blends have higher heat release rate in uncontrolled combustion and lesser HRR in mixture controlled combustion. Thisresult shows that the ignition delay of the diesel gets reduced with an increase in load. The peak value of HRR for M10 and M20 blends are 7.09 J/CA and 4.61 J/CA. Dueto the lower calorific value of the biodiesel. The addition of Nanofluid in biodiesel blends to improve the reactive surfaces of fuel molecules which resulted in enhanced heat release rate leads to complete combustion. The heat release

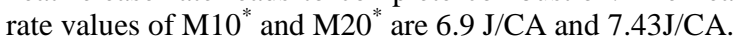

Figure 8 shows the variation of pressure crank angle for diesel and biodiesel blends with crank angle. Thepeak pressure of diesel increases with load. The peak pressure for M10 and M20 biodiesel blends are 51.4 bar and 51.56 bar lower than that of pure diesel pressure of 60.39 bar. For mixing alumina Nanofluid on biodiesel blends shows increased peak pressure in $\mathrm{M} 0^{*}$ and $\mathrm{M} 20^{*}$ are 56.53 bar and 57.92 bar.

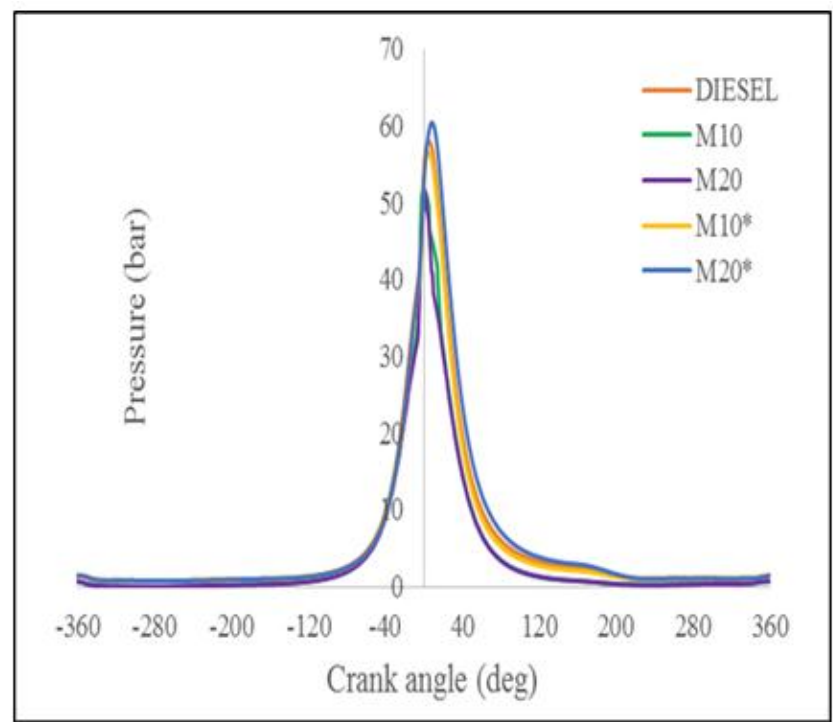

Fig. 8: Variation of pressure with crank Angle

\section{Emission characteristics}

Figure 9 shows the variation of unburned $\mathrm{HC}$ emission with brake power of M10, M20 is $11 \mathrm{ppm}$ and 21ppm decreases than diesel due to higher cetane number of the biodiesel results in lesser ignition delay than diesel. The reduction of ignition delay indirectly indicates the activation energy needed to start the combustion is less compared to diesel. Therefore HC emission of blended fuel is lower than diesel. The unburned $\mathrm{HC}$ values of M10* and M20* are 4ppm and 1ppm decreases than M10, M20 fuel blends.

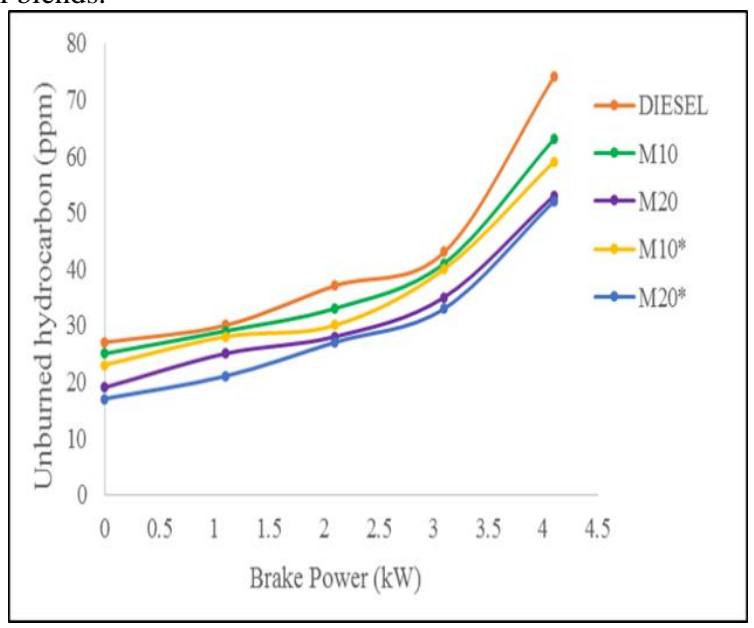

Fig. 9: Variation of $\mathrm{HC}$ with $\mathrm{BP}$ 
The variation of $\mathrm{CO}$ emission of diesel and biodiesel blends with brake power (bp) as shown in fig. 10. The carbon monoxide emission of M10, M20 are $15.74 \%$ and $21.3 \%$ decreases than diesel. The CO emission increases with increase in load for all blends and pure fuels. Blends of biodiesel give less $\mathrm{CO}$ emissions than diesel. The oxygen content in the biodiesel would have converted $\mathrm{CO}$ to $\mathrm{CO} 2$ resulting in less $\mathrm{CO}$ emission. The $\mathrm{CO}$ emission of $\mathrm{M}^{2} 0^{*}, \mathrm{M} 20^{*}$ values are $3.19 \%$ and $5.82 \%$ decreased than M10 and M20 emission values.

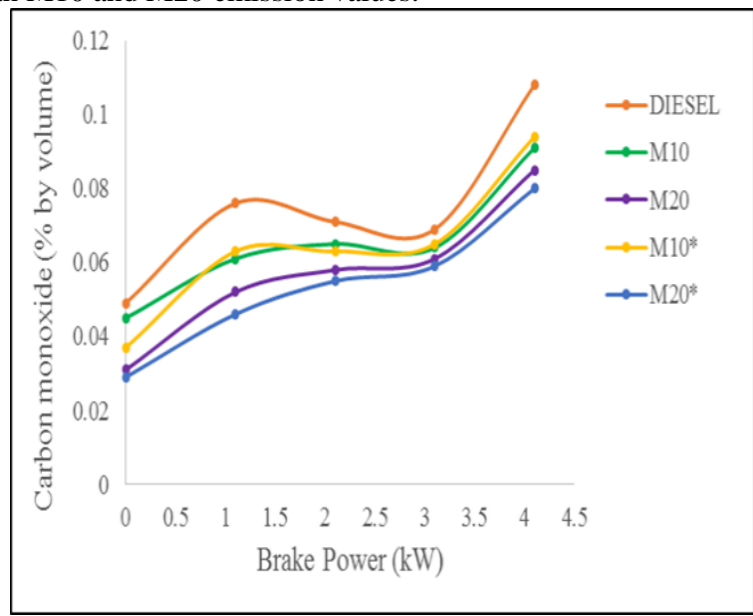

Fig. 10: Variation of $\mathrm{CO}$ with $\mathrm{BP}$

Figure 11 shows the variation of diesel and biodiesel blends of $\mathrm{NO}_{\mathrm{x}}$ emission with engine brake power at maximum load conditions. The biodiesel blends of M10 and M20 emission values are $147 \mathrm{ppm}$ and $69 \mathrm{ppm}$ decreases than diesel. Because of the inferior combustion which reduced the peak cycle temperature leads to lower $\mathrm{NO}_{\mathrm{x}}$ emissions than diesel. Adding Nanofluids on the biodiesel blends results in lower $\mathrm{NO}_{\mathrm{x}}$ emission than M10 and M20 fuel blends. Dueto the thermal stability of alumina Nanofluids causing reduction of high-temperature attainment and fast evaporation rate during the combustion process. The reduced $\mathrm{NO}_{\mathrm{x}}$ emission values of $\mathrm{M} 10^{*}$ and $\mathrm{M} 20^{*}$ are $66 \mathrm{ppm}$ and $25 \mathrm{ppm}$ than M10 and M20 emission levels.

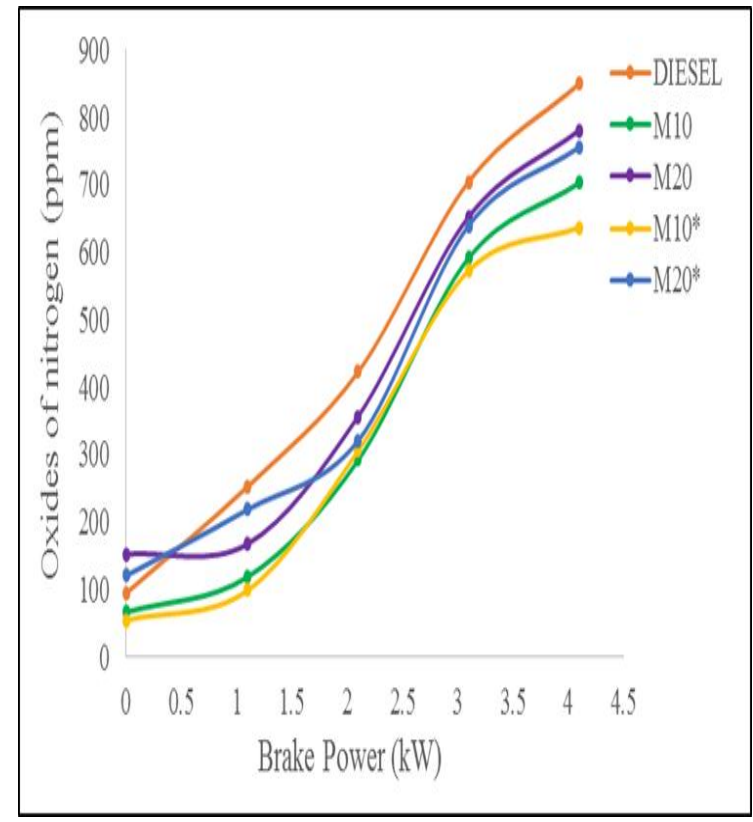

Fig. 11: Variation of $\mathrm{NO}_{x}$ with $\mathrm{BP}$

Figure 12 shows the comparison of diesel and biodiesel smoke emission. The smoke value of M10, M20 are $46.41 \%$ and $61.2 \%$ lower than pure diesel at maximum power output due to poor atomization and vaporisation of diesel fuel. Whether the mixing of alumina Nanofluid in biodiesel blends in volume fraction, namely as $\mathrm{M}^{*} 0^{*}$ and $\mathrm{M} 20^{*}$. These blends have reduced the percentage of smoke emission of $1.97 \%$ and $0.74 \%$ from M10 and M20 values due to the reduction of ignition temperature with metal-based additives in Nanofluids.

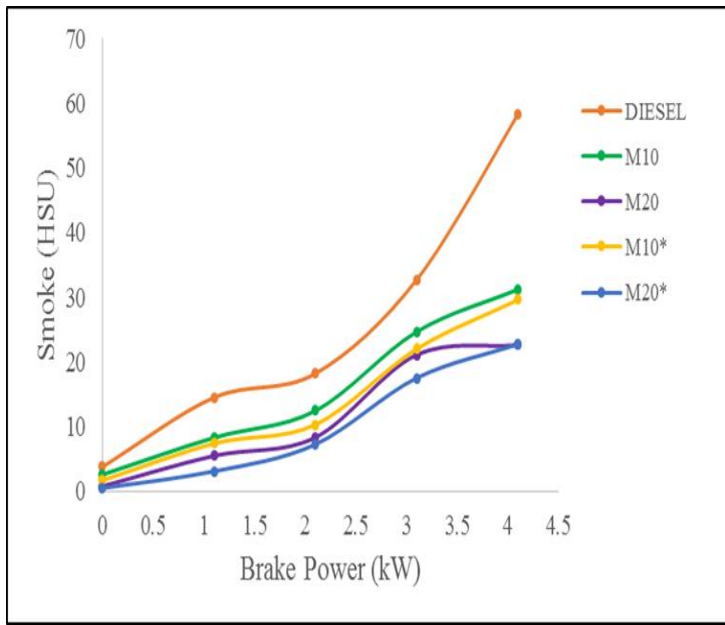

Fig. 12: Variation of Smoke with BP

\section{Conclusion}

Following conclusions are made based on the report of the theoretical study and experimental investigation carried out on single cylinder direct injection diesel engine.

Performance characteristics of the biodiesel and its blend of diesel are lower than pure diesel due to its lower calorific value. Brake thermal efficiency of M10, M20 are $5.15 \%$ and $7.51 \%$ less than diesel. But the brake thermal efficiency of $\mathrm{M}^{*}{ }^{*}$ and M20* improved about $0.76 \%$ and $0.93 \%$ than M10, M20. The addition of alumina Nanofluids in biodiesel blends to promote the more reactive surfaces of fuel molecules leads to the improved combustion process.

The brake specific energy consumption of M10 and M20 are $11.19 \%$ and $18.94 \%$ increase than diesel due to slightly higher viscosity and density of biodiesel blends. When compared to M10* and M20* values with M10, M20 fuel blends resulted in percentage decrease of $2.98 \%$ and $1.56 \%$.

The emissions from test engine reduce for M10 was obtained $11 \mathrm{ppm}, 15.74 \%, 147 \mathrm{ppm}$ and $46.4 \%$ of HC, CO, NOx, and smoke respectively compared to diesel fuel. Similarly, the amount of HC, $\mathrm{CO}, \mathrm{NOx}$, and smoke gets lowered for M20 was obtained 21ppm, $21.3 \%, 69 \mathrm{ppm}$ and $61.2 \%$. The $\mathrm{M} 10^{*}$ biodiesel blend resulted in well-reduced emission levels are 4ppm, 3.19\%, 66ppm and 5.21\% than that of M10. Whether M20* blend emission values are reduced to 2ppm, 5.8\%, 25ppm and $0.53 \%$ than M20 blend. Due tothe presence of nanofluidminimizes the equivalence ratio of combustive products leads to improved atomization and effective distribution of air-fuel mixture causing a reduction in emission levels of the test engine. Finally, this experimental analysis concluded with the $\mathrm{M} 20^{*}$ blend is an optimum blend for a conventional diesel engine.

\section{Nomenclature}

\begin{tabular}{|c|l|}
\hline Acronym & \multicolumn{1}{c|}{ Abbreviation } \\
\hline M 10 & fuel blend of mahua biodiesel $10 \%+$ diesel $90 \%$ \\
\hline M 20 & fuel blend of mahua biodiesel $20 \%+$ diesel $80 \%$ \\
\hline M $10 *$ & $\begin{array}{l}\text { fuel blend of mahua biodiesel } 10 \%+\text { diesel } 90 \%+2 \mathrm{ml} \text { of } \\
\text { aluminium oxide Nanofluid }\end{array}$ \\
\hline M $20 *$ & $\begin{array}{l}\text { fuel blend of mahua biodiesel } 20 \%+\text { diesel } 80 \%+2 \mathrm{ml} \text { of } \\
\text { aluminium oxide Nanofluid }\end{array}$ \\
\hline BP & Brake Power \\
\hline BTE & Brake Thermal Efficiency \\
\hline BSEC & Brake Specific Energy Consumption \\
\hline HC & Hydrocarbon \\
\hline CO & Carbon Monoxide \\
\hline NO $_{\mathrm{X}}$ & Oxides of Nitrogen \\
\hline
\end{tabular}




\section{References}

[1] Ram R, "Effect on Performance and Emission Characteristics on Direct Injection Diesel Engine Fueled with Mahua Biodiesel", ENVIRONMENTAK SYSTEMS AND SUSTAINABLE DEVELOPMENT, (2016).

[2] Sajeevan AC \& Sajith V, "Diesel Engine Emission Reduction Using Catalytic Nanoparticles: An Experimental Investigation", J. Eng., (2013).

[3] Jayaprabakar J, Palaniappan PL \& Mohankumar B, "Investigating the performance and emission characteristics of an SI engine using Peltier element cooling effect", Int. J. Ambient Energy, (2016).

[4] Nayak SK \& Pattanaik BP, "Experimental investigation on performance and emission characteristics of a diesel engine fuelled with mahua biodiesel using an additive", Energy Procedia, Vol.54, (2014), pp.569-579.

[5] Sanjay KC, Pinto V, Shoaib S, Gafoor A, Biju T \& Raju K, "Effect of Alumina Nanoparticles on the Performance and Emission Characteristics of CI Engine Fuelled with Lard Oil Methyl Ester Blends", American Journal of Materials Science, Vol.6, No.4A,(2016), pp.94-98.

[6] Ganesan V, Internal Combustion Engines, fourth ed., McGraw Hill Education (India) Private Limited, New Delhi, (2013).

[7] Kim MJ, "Study on the Adsorption and Desorption Enhance Effect of Oyster Shell Using Peltier Element", J. Korea Soc. Power Syst. Eng., Vol.17, No.1, (2013), pp.71-76.

[8] Pundir BP, Engine Emissions, Narosa Publishing Pvt Ltd., New Delhi, (2012).

[9] Shaa T \& Velraj R, "Influence of alumina nanoparticles, ethanol and isopropanol blend as additive with diesel e soybean biodiesel blend fuel : Combustion, engine performance and emissions", Renewable Energy, Vol.80, (2015), pp.655-663.

[10] Khond VW \& Kriplani VM, "Effect of nanofluid additives on performances and emissions of emulsified diesel and biodiesel fueled stationary CI engine: A comprehensive review", Renew. Sustain. Energy Rev., Vol.59, (2016), 1338-1348.

[11] Hakimi I, Nikulshin Y, Wolfus S \& Yeshurun Y. "Peltier Current Leads with conical configuration", Cryogenics (Guildf)., Vol.75, (2016), pp.1-5.

[12] Kegl B, "Influence of biodiesel on engine combustion and emission characteristics", Appl. Energy, Vol.88, No.5, (2011), 1803-1812. 